\title{
REACTION KINETICS OF CARBON DIOXIDE IN AQUEOUS DIETHANOLAMINE SOLUTIONS USING THE STOPPED-FLOW TECHNIQUE
}

\author{
KINETYKA REAKCJI DITLENKU WEGLA \\ W WODNYCH ROZTWORACH DIETANOLOAMINY \\ Z ZASTOSOWANIEM TECHNIKI ZATRZYMANEGO PRZEPLYWU
}

\begin{abstract}
The pseudo-first-order rate constants $(\mathrm{kOV})$ for the reactions between $\mathrm{CO}_{2}$ and diethanolamine have been studied using the stopped-flow technique in an aqueous solution at 293, 298, 303 and $313 \mathrm{~K}$. The amine concentrations ranged from 167 to $500 \mathrm{~mol} \cdot \mathrm{m}^{-3}$. The overall reaction rate constant was found to increase with amine concentration and temperature. Both the zwitterion and termolecular mechanisms were applied to correlate the experimentally obtained rate constants. The values of SSE quality index showed a good agreement between the experimental data and the corresponding fit by the use of both mechanisms.
\end{abstract}

Keywords: reaction kinetics, $\mathrm{CO}_{2}$ absorption, kinetic model, diethanolamine, stopped-flow technique

Carbon dioxide $\left(\mathrm{CO}_{2}\right)$ emission is still increasing because of increasing energy demand. This causes that greenhouse effect becomes more intensive and therefore governments, industries and researchers are becoming increasingly interested in $\mathrm{CO}_{2}$ capture from gas streams. Reactions of carbon dioxide with amines have been used for gas sweetening on a commercial scale for more than 75 years. Stripping carbon dioxide from gas streams with alkanolamines allows also removing the hydrogen sulphide $\left(\mathrm{H}_{2} \mathrm{~S}\right)$. In these processes the most widely used amines are monoethanolamine (MEA), diethanolamine (DEA) and methyldiethanolamine (MDEA).

Diethanolamine is very popular and reaction kinetics of $\mathrm{CO}_{2}$ in aqueous DEA was widely investigated. Secondary alkanolamines like DEA react rapidly with $\mathrm{CO}_{2}$ to form carbamates. The reaction of $\mathrm{CO}_{2}$ with secondary amines is usually described by the zwitterion mechanism. However, the results of kinetic studies are still confusing and conflicting and there are many discrepancies in the literature concerning the interpretation of the kinetic data. The main reasons of this disagreement are diversity of research methods

\footnotetext{
${ }^{1}$ Faculty of Process and Environmental Engineering, Technical University of Lodz, ul. Wólczańska 213, 90-924 Łódź, Poland, phone +48 4263137 00, fax +48 426365663

*Corresponding author: marta.siemieniec@ wipos.p.lodz.pl
} 
and usage of different mechanisms including zwitterion or termolecular one to correlate the experimentally obtained rate constants. This causes the relatively high difference in the forward rate constant of the reaction between DEA and $\mathrm{CO}_{2}$ which is ranging from $0.81 \mathrm{~m}^{3} \mathrm{~mol}^{-1} \mathrm{~s}^{-1}$ [1] to $8.59 \mathrm{~m}^{3} \mathrm{~mol}^{-1} \mathrm{~s}^{-1}$ [2] at $298 \mathrm{~K}$. Even adoption of the same experimental technique does not ensure that the kinetic data are reproducible. For example, Laddha et al [2] and Versteeg et al [3] used stirred reactors for experiments but they obtained the forward rate constant of $8.59 \mathrm{~m}^{3} \mathrm{~mol}^{-1} \mathrm{~s}^{-1}$ and $5.79 \mathrm{~m}^{3} \mathrm{~mol}^{-1} \mathrm{~s}^{-1}$ at $298 \mathrm{~K}$, respectively.

The most widely used techniques for the kinetic measurements are indirect methods involving gas-phase absorption in such kinds of apparatus like a laminar jet absorber, a stirred cell with a flat gas-liquid interface, a wetted-wall column and a disc absorption column. In this work, experiments were performed using the conductometric stopped-flow technique, where both reagents (DEA and $\mathrm{CO}_{2}$ ) are present in aqueous solutions before mixing. Therefore, the results of the direct method used here correspond to the intrinsic homogeneous reaction rate in aqueous medium. It is worth to add that this is the first research on reaction kinetics between $\mathrm{CO}_{2}$ and DEA using Fast-Fourier-Transform (FFT) technique, in which an alternating current is applied for signal detection.

\section{Reaction mechanism}

Reactions between $\mathrm{CO}_{2}$ and primary or secondary amines can be described using two different mechanisms: zwitterion and termolecular one.

The zwitterion mechanism was proposed for the first time by Caplow [4] and was widely used by several investigators. This mechanism comprises two steps: formation of the $\mathrm{CO}_{2}$ amine zwitterion intermediate, followed by deprotonation by a base. It is only a hypothesis because the zwitterion forms quite slow but breaks very fast and in this stage of knowledge there is no detection technique which would allow to confirm whether the zwitterion really exists or not.

Firstly, $\mathrm{CO}_{2}$ reacts with amine to form the zwitterion intermediate according to:

$$
\mathrm{CO}_{2}+\mathrm{R}_{1} \mathrm{R}_{2} \mathrm{NH} ? \stackrel{\mathrm{k}_{2}, \mathrm{k}_{-1}}{\longleftarrow} \mathrm{R}_{1} \mathrm{R}_{2} \mathrm{NH}^{+} \mathrm{COO}^{-}
$$

Then the zwitterion is deprotonated by a base to produce carbamate and protonated base according to:

$$
\mathrm{R}_{1} \mathrm{R}_{2} \mathrm{NH}^{+} \mathrm{COO}^{-}+\mathrm{B} \stackrel{\mathrm{k}_{\mathrm{B}}, \mathrm{k}_{-\mathrm{B}}}{\longleftarrow} \mathrm{R}_{1} \mathrm{R}_{2} \mathrm{NCOO}^{-}+\mathrm{BH}^{+}
$$

Any base present in the solution eg amine itself, water molecules or hydroxyl ions, may contribute to the deprotonation of the zwitterion. In aqueous DEA solutions the corresponding reactions are taking place:

$$
\begin{gathered}
\mathrm{R}_{1} \mathrm{R}_{2} \mathrm{NH}^{+} \mathrm{COO}^{-}+\mathrm{R}_{1} \mathrm{R}_{2} \mathrm{NH} \stackrel{\mathrm{k}_{\mathrm{R}_{1} \mathrm{R}_{2} \mathrm{NH}}}{\longrightarrow} \mathrm{R}_{1} \mathrm{R}_{2} \mathrm{NCOO}^{-}+\mathrm{R}_{1} \mathrm{R}_{2} \mathrm{NH}_{2}^{+} \\
\mathrm{R}_{1} \mathrm{R}_{2} \mathrm{NH}^{+} \mathrm{COO}^{-}+\mathrm{H}_{2} \mathrm{O} \stackrel{\mathrm{k}_{\mathrm{H}_{2} \mathrm{O}}}{\longrightarrow} \mathrm{R}_{1} \mathrm{R}_{2} \mathrm{NCOO}^{-}+\mathrm{H}_{3} \mathrm{O}^{+} \\
\mathrm{R}_{1} \mathrm{R}_{2} \mathrm{NH}^{+} \mathrm{COO}^{-}+\mathrm{OH}^{-} \stackrel{\mathrm{k}_{\mathrm{OH}-}}{\longrightarrow} \mathrm{R}_{1} \mathrm{R}_{2} \mathrm{NCOO}^{-}+\mathrm{H}_{2} \mathrm{O}
\end{gathered}
$$


In this mechanism, a quasi-steady state condition for the zwitterion concentration is assumed. It means that the zwitterion concentration is constant in time and very small comparing with concentrations of substrates and products. In this situation the overall forward reaction rate equation for this reaction can be expressed as:

$$
\mathrm{r}=\frac{\mathrm{k}_{2}\left[\mathrm{CO}_{2}\right]\left[\mathrm{R}_{1} \mathrm{R}_{2} \mathrm{NH}\right]}{1+\frac{\mathrm{k}_{-1}}{\left(\mathrm{k}_{\mathrm{H}_{2} \mathrm{O}}\left[\mathrm{H}_{2} \mathrm{O}\right]+\mathrm{k}_{\mathrm{OH}-}\left[\mathrm{OH}^{-}\right]+\mathrm{k}_{\mathrm{R}_{1} \mathrm{R}_{2} \mathrm{NH}}\left[\mathrm{R}_{1} \mathrm{R}_{2} \mathrm{NH}\right]\right)}}
$$

Versteeg and van Swaaij [3] concluded that in aqueous DEA the contribution of hydroxyl ion to the deprotonation of the zwitterion can be neglected due to its very low concentration. Moreover, most of the researchers neglected the contribution of water to the deprotonation of the zwitterion so that equation (6) reduces to:

$$
\mathrm{r}=\frac{\mathrm{k}_{2}\left[\mathrm{CO}_{2}\right]\left[\mathrm{R}_{1} \mathrm{R}_{2} \mathrm{NH}\right]}{1+\frac{\mathrm{k}_{-1}}{\mathrm{k}_{\mathrm{R}_{1} \mathrm{R}_{2} \mathrm{NH}}\left[\mathrm{R}_{1} \mathrm{R}_{2} \mathrm{NH}\right]}}
$$

Under pseudo-first-order conditions with respect to $\mathrm{CO}_{2}$, when the concentration of DEA is much in excess of that of $\mathrm{CO}_{2}$, which means that the concentration ratio $[\mathrm{DEA}] /\left[\mathrm{CO}_{2}\right]$ is at least 10 , the reaction rate equation takes the form:

$$
\mathrm{r}=\mathrm{k}_{\mathrm{OV}}\left[\mathrm{CO}_{2}\right]
$$

Therefore, the observed pseudo-first-order reaction rate constant $\left(\mathrm{k}_{\mathrm{OV}}\right)$ can be obtained by:

$$
\mathrm{k}_{\mathrm{OV}}=\frac{\mathrm{k}_{2}\left[\mathrm{R}_{1} \mathrm{R}_{2} \mathrm{NH}\right]}{1+\frac{\mathrm{k}_{-1}}{\mathrm{k}_{\mathrm{R}_{1} \mathrm{R}_{2} \mathrm{NH}}\left[\mathrm{R}_{1} \mathrm{R}_{2} \mathrm{NH}\right]}}
$$

After introducing the following notation:

$$
\mathrm{k}_{\mathrm{a}}=\frac{\mathrm{k}_{2} \cdot \mathrm{k}_{\mathrm{R}_{1} \mathrm{R}_{2} \mathrm{NH}}}{\mathrm{k}_{-1}}
$$

the equation (9) takes the form:

$$
\mathrm{k}_{\mathrm{OV}}=\frac{\left[\mathrm{R}_{1} \mathrm{R}_{2} \mathrm{NH}\right]}{\frac{1}{\mathrm{k}_{2}}+\frac{1}{\mathrm{k}_{\mathrm{a}}\left[\mathrm{R}_{1} \mathrm{R}_{2} \mathrm{NH}\right]}}
$$

In equation (11) only the rate constant $\mathrm{k}_{2}$ has a strict physical meaning - it is the reaction rate constant for the zwitterion formation described by equation (1). The $k_{a}$ term is a combination of other constants. Constant $\mathrm{k}_{\mathrm{a}}$ has no physical meaning and in this stage of knowledge there is no detection technique which would allow to determine the $\mathrm{k}_{-1}$ and $\mathrm{k}_{\mathrm{R} 1 \mathrm{R} 2 \mathrm{NH}}$ values which are incorporated in $\mathrm{k}_{\mathrm{a}}$ term.

The termolecular mechanism is another one mechanism describing the reaction of $\mathrm{CO}_{2}$ with primary or secondary alkanolamines. This mechanism, originally proposed by Crooks and Donnellan [5] assumes that the reaction takes place in a single step. The validity of this mechanism is questionable because from probability point of view it is almost impossible 
that three molecules will be able to meet and react every time. It is assumed that water acts both as a solvent and as a reagent. There is always one molecule of water in surroundings of $\mathrm{CO}_{2}$ and amine molecules because water is in much excess in comparison with $\mathrm{CO}_{2}$ and amine. In this situation carbon dioxide reacts simultaneously with two molecules of amine or with one molecule of amine and one molecule of water. According to this theory, the corresponding reactions occur:

$$
\begin{gathered}
\mathrm{CO}_{2}+2 \mathrm{R}_{1} \mathrm{R}_{2} \mathrm{NH} \stackrel{\mathrm{k}_{1}^{\prime}}{\longleftarrow} \mathrm{R}_{1} \mathrm{R}_{2} \mathrm{NCOO}^{-}+\mathrm{R}_{1} \mathrm{R}_{2} \mathrm{NH}_{2}^{+} \\
\mathrm{CO}_{2}+\mathrm{R}_{1} \mathrm{R}_{2} \mathrm{NH}+\mathrm{H}_{2} \mathrm{O} \stackrel{\mathrm{k}_{2}^{\prime}}{\longleftarrow} \mathrm{R}_{1} \mathrm{R}_{2} \mathrm{NCOO}^{-}+\mathrm{H}_{3} \mathrm{O}^{+}
\end{gathered}
$$

The forward reaction rate for the termolecular mechanism is given by:

$$
\mathrm{r}=\left(\mathrm{k}_{1}^{\prime}\left[\mathrm{R}_{1} \mathrm{R}_{2} \mathrm{NH}\right]+\mathrm{k}_{2}^{\prime}\left[\mathrm{H}_{2} \mathrm{O}\right]\right) \cdot\left[\mathrm{R}_{1} \mathrm{R}_{2} \mathrm{NH}\right] \cdot\left[\mathrm{CO}_{2}\right]
$$

Under pseudo-first-order conditions with respect to $\mathrm{CO}_{2}$, the reaction rate equation takes the form:

$$
\mathrm{r}=\mathrm{k}_{\mathrm{OV}}\left[\mathrm{CO}_{2}\right]
$$

where $\mathrm{k}_{\mathrm{OV}}$ denotes the observed reaction rate constant which can be measured and is given by:

$$
\mathrm{k}_{\mathrm{OV}}=\left(\mathrm{k}_{1}^{\prime}\left[\mathrm{R}_{1} \mathrm{R}_{2} \mathrm{NH}\right]+\mathrm{k}_{2}^{\prime}\left[\mathrm{H}_{2} \mathrm{O}\right]\right) \cdot\left[\mathrm{R}_{1} \mathrm{R}_{2} \mathrm{NH}\right]
$$

In general, the most widely used interpretation for the reaction of $\mathrm{CO}_{2}$ in secondary amines solutions is the zwitterion mechanism. Henni [6] stressed that the zwitterion mechanism has modelled with success all published $\mathrm{CO}_{2}$ aqueous and non-aqueous amine systems and the majority of the researchers use it to regress values of the second-order reaction rate constant. But the only reason for this is that there is no better model based on physical evidence.

\section{Experimental apparatus and procedure}

The experimental technique considered in this study is a direct method using the SFM-20 stopped-flow system, designed for single mixing rapid-kinetics applications. The SFM-20 module is connected with MCS-200 module allowing conductivity measurements. The whole experimental equipment is manufactured by Bio-Logic SAS (France).

The Bio-Logic stopped-flow module SFM-20 consists of two syringe driving systems based on stepping motors, drive screws, an observation cuvette and a valve system allowing isolation of the cuvette. All parts are enclosed in a water jacket to allow temperature regulation of the reactants. The SFM module is connected to a circulating temperature bath for temperature regulation. The coolant flows through two internal circuits: around the injection syringes and through the isolation valve block and observation head [7]. The syringe plungers are driven by two independent stepping motors which can be activated manually or automatically. The manual mode is mainly used to refill or wash the syringes; 
the automatic mode - for experiments. Figure 1 shows a schematic drawing of the stopped-flow equipment used in the present study.

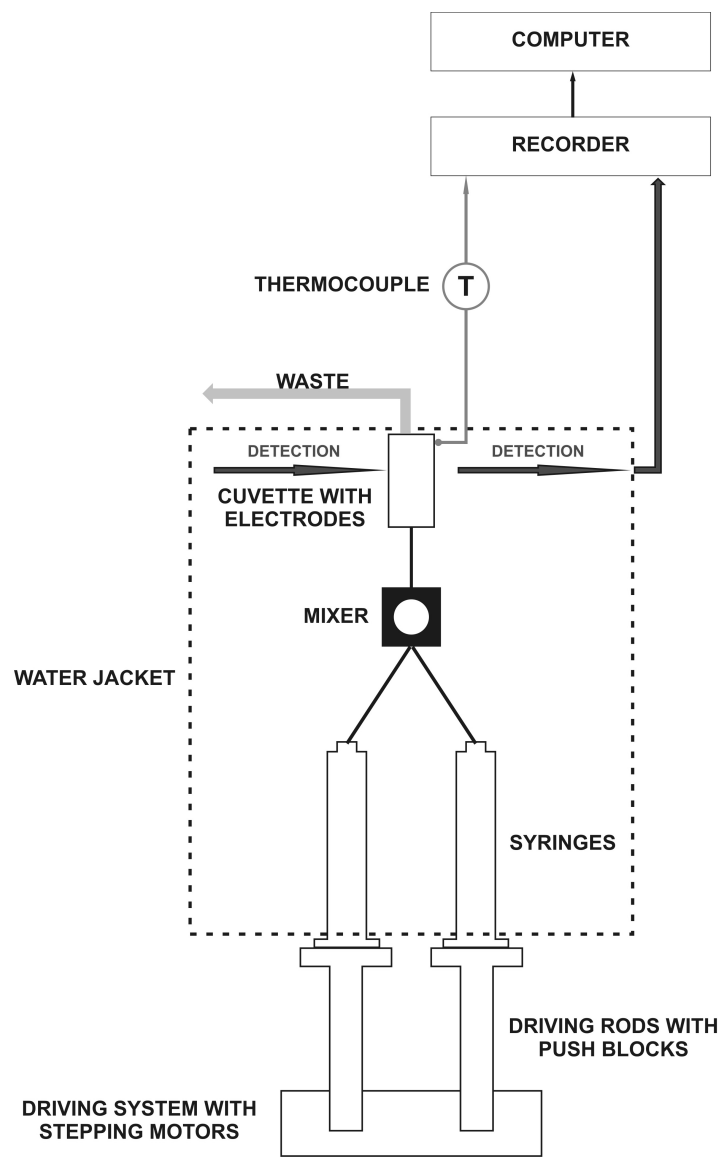

Fig. 1. SFM-20 schematic drawing of the experimental set-up

The experimental method used in this research involves the measurement of the solution's electrical resistance or conductance. The Modular Conductivity System, MCS-200, is a rapid impedance spectrometer. The MCS-200 consists of an impedance spectrometer unit and a special observation head with an observation cuvette that contains two electrodes made from glassy carbon. It allows to measure steady-state spectra of the impedance of a solution and to follow rapid changes in the solution's impedance in the course of a chemical reaction. The principle of the detection technique is to impose a high-frequency electrical voltage in the solution between two electrodes and to follow the time course of the resulting current. By means of a Fast-Fourier-Transform (FFT) technique, the two components of the complex impedance - the real part called resistance and the imaginary part called reactance - can be computed at sampling rates up to $200 \mu \mathrm{s}$ per data point [8]. 
In the experiment, diethanolamine solution and aqueous solution of $\mathrm{CO}_{2}$ are pushed into a mixer where they react. As the reaction proceeds, the conductivity of a mixture of amine, water and $\mathrm{CO}_{2}$ increases as the ionic products are formed. The measured data are plotted and displayed on the screen at the end of the entire acquisition. Display of data is either in resistance values ( $\mathrm{R}$ in $\mathrm{Ohm}$ ) or in conductivity ( $\mathrm{L}$ in Siemens/cm). The electrical cell constant $\mathrm{k}=8 \mathrm{~cm}^{-1}$ is used to convert data automatically according to the following formula: $\mathrm{L}=\mathrm{k} / \mathrm{R}$.

Reagent-grade DEA with a purity of $99 \%$ was obtained from Sigma-Aldrich and used without further purification. Ultra-pure water was used to prepare both amine and $\mathrm{CO}_{2}$ solutions. For each experiment, freshly saturated $\mathrm{CO}_{2}$ solution was prepared by mixing the gas through the water in a jacketed glass stirred reactor. Owing to the independent control of each syringe it was possible to make variable reagents mixing ratios to ensure an appropriate ratio of amine molar concentration to $\mathrm{CO}_{2}$ molar concentration after mixing for each experiment. DEA was used in excess and the concentration ratio [DEA]:[CO $\left.\mathrm{CO}_{2}\right]$ was at least 10. Owing to such a concentration ratio it could be assumed that the amine concentration is constant during the experiment and the reaction occurs in the pseudo-first-order regime.

In this work, the overall reaction rate constant $\mathrm{k}_{\mathrm{OV}}$ was assessed as the average of 15 shots at each temperature for all amine concentrations. Measurements were performed in the temperature range of $293 \div 313 \mathrm{~K}$. The amine concentration varied from 167 to $500 \mathrm{~mol} / \mathrm{m}^{3}$. A set of runs was performed to measure the kinetics of DEA with $\mathrm{CO}_{2}$ in terms of $\mathrm{k}_{\mathrm{OV}}$ and the results were compared with the corresponding published data. Both the termolecular and zwitterion mechanisms were applied to correlate the experimentally obtained rate constants. All individual rate constants including $\mathrm{k}_{2}, \mathrm{k}_{\mathrm{a}}, \mathrm{k}_{1}$ ' and $\mathrm{k}_{2}$ ' were expressed by the Arrhenius equation.

\section{Results and discussion}

"Bio-Kine32 v.4.51" software is an integral element of experimental set-up. It allowed to obtain the pseudo-first-order reaction rate constant $\mathrm{k}_{\mathrm{OV}}$ values occurred in equations (8) and (15) directly from the measured conductivity data.

The obtained values of the pseudo-first-order reaction rate constant $\mathrm{k}_{\mathrm{OV}}$

Table 1

\begin{tabular}{|c|c|c|c|c|}
\hline \multirow{2}{*}{ DEA $\left[\mathbf{k m o l} / \mathbf{m}^{\mathbf{3}}\right]$} & \multicolumn{4}{|c|}{$\mathbf{k}_{\mathbf{O V}}\left[\mathbf{s}^{\mathbf{- 1}}\right]$} \\
\cline { 2 - 5 } & $\mathbf{2 9 3} \mathbf{~ K}$ & $\mathbf{2 9 8} \mathbf{~ K}$ & $\mathbf{3 0 3} \mathbf{~ K}$ & $\mathbf{3 1 3 ~ K}$ \\
\hline 0.167 & 26.7 & 36.0 & 44.3 & 65.2 \\
\hline 0.200 & 38.1 & 42.8 & 58.2 & 88.5 \\
\hline 0.250 & 59.3 & 72.7 & 99.0 & 137.8 \\
\hline 0.300 & 83.4 & 98.7 & 135.9 & 198.1 \\
\hline 0.333 & 101.6 & 120.2 & 163.7 & 228.3 \\
\hline 0.375 & 114.2 & 137.2 & 174.4 & 240.5 \\
\hline 0.400 & 124.4 & 148.8 & 184.5 & 333.1 \\
\hline 0.429 & 133.8 & 175.7 & 217.9 & 341.4 \\
\hline 0.455 & 142.4 & 184.5 & 226.5 & 346.7 \\
\hline 0.474 & 167.0 & 197.7 & 248.0 & 408.0 \\
\hline 0.500 & 172.8 & 236.5 & 255.6 & \\
\hline
\end{tabular}


Kinetics rate data for $\mathrm{CO}_{2}$ into aqueous DEA solutions were analyzed to determine the kinetics parameters associated with the reaction. The effect of concentration of the aqueous solution of DEA on the kinetics of reaction between DEA and $\mathrm{CO}_{2}$ was studied at 293, 298, 303 and $313 \mathrm{~K}$. As expected, for a given amine concentration, the reaction kinetics increases when the temperature increases. Moreover, for a given temperature, the $\mathrm{k}_{\mathrm{OV}}$ values increase when amine concentration increases. The obtained values of the pseudo-first-order reaction rate constant $\mathrm{k}_{\mathrm{OV}}$ are presented in Table 1 .

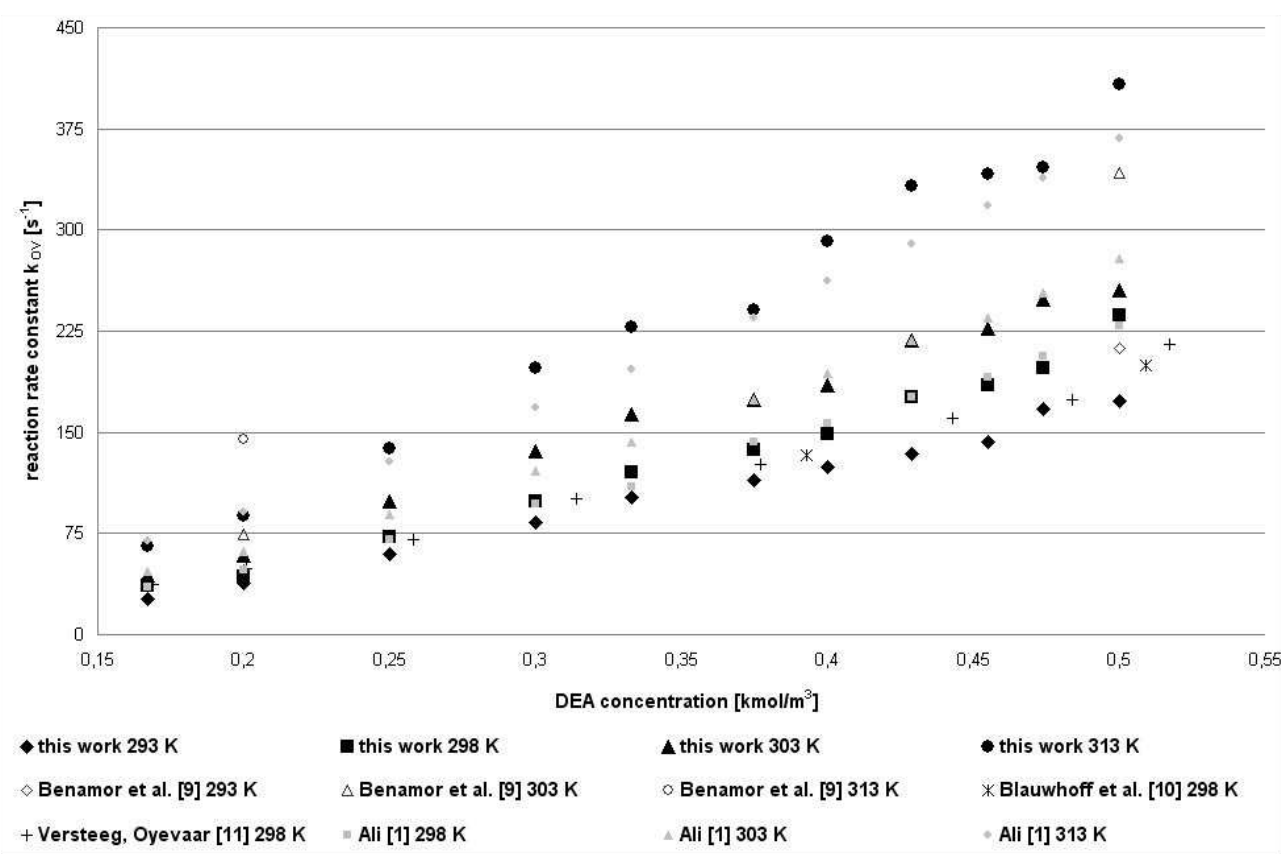

Fig. 2. Comparison of pseudo-first-order reaction rate constant values obtained by different authors

Figure 2 shows a plot comparing the observed pseudo-first-order reaction rate constant $\mathrm{k}_{\mathrm{OV}}$ obtained in this work with previously published data by the use of different research methods. From that plot a conclusion can be drawn that data obtained using stopped-flow with an alternating current signal detection are comparable with data published by other researchers. It is worth to add that stopped-flow method has one significant advantage owing to a small cuvette volume, rapid mixing and short dead time it is possible to make measurements for very fast reactions what is not always possible for other absorption apparatus like stirred reactors or laminar-liquid jet absorbers.

Both the termolecular and zwitterion mechanisms were applied to correlate the experimentally obtained pseudo-first-order reaction rate constants. Correlation results are illustrated in Figures 3 and 4. From these plots a conclusion can be drawn that the zwitterion mechanism approximates experimental data as well as termolecular. From mathematical point of view both models are equal valuable and in this stage of knowledge it is impossible to state which one is more reasonable. 
Both kinetic models based on zwitterion and termolecular mechanisms, were used to identify kinetic parameters associated with the reaction between $\mathrm{CO}_{2}$ and DEA from the obtained experimental data. The individual parameters were determined by minimizing the quality index defined by the following formula:

$$
\mathrm{SSE}=\sum_{\mathrm{i}=1}^{\mathrm{n}} \sum_{\mathrm{j}=1}^{\mathrm{m}}\left(\mathrm{k}_{\mathrm{OV}}^{\exp }-\mathrm{k}_{\mathrm{OV}}^{\mathrm{cal}}\right)^{2}
$$

In the equation (17), the internal summation refers to the concentration of amine, while external one to the process temperature. A minimum quality index was determined by the Marquardt method [12]. Table 2 gives the values of kinetic parameters that minimize the quality index for both kinetic models. The values of SSE quality index showed a good agreement between the experimental data and the corresponding fit by the use of both mechanisms. Therefore, from mathematical point of view both models are equal valuable. Table 3 shows the dependence between obtained reaction rate constants from both mechanisms and process temperature.

Table 2

Kinetic parameters of two reaction models

\begin{tabular}{|c|c|c|c|}
\hline \multicolumn{4}{|c|}{ Zwitterion mechanism } \\
\hline Kinetic parameter & Unit & Value & SSE \\
\hline $\mathrm{k}_{02}$ & {$\left[\mathrm{~m}^{3} \mathrm{~mol}^{-1} \mathrm{~s}^{-1}\right]$} & $3.3603 \cdot 10^{4}$ & \multirow{4}{*}{$3.2699 \cdot 10^{3}$} \\
\hline $\mathrm{E}_{\mathrm{A} 2}$ & {$[\mathrm{~J} / \mathrm{mol}]$} & $2.6380 \cdot 10^{4}$ & \\
\hline $\mathrm{k}_{0 \mathrm{a}}$ & {$\left[\mathrm{m}^{6} \mathrm{~mol}^{-2} \mathrm{~s}^{-1}\right]$} & $6.0056 \cdot 10^{3}$ & \\
\hline $\mathrm{E}_{\mathrm{Aa}}$ & {$[\mathrm{J} / \mathrm{mol}]$} & $3.7115 \cdot 10^{4}$ & \\
\hline \multicolumn{4}{|c|}{ Termolecular mechanism } \\
\hline Kinetic parameter & Unit & Value & SSE \\
\hline $\mathrm{k}_{01}{ }^{\prime}$ & {$\left[\mathrm{m}^{6} \mathrm{~mol}^{-2} \mathrm{~s}^{-1}\right]$} & 0.9732 & \multirow{4}{*}{$4.5994 \cdot 10^{3}$} \\
\hline $\mathrm{E}_{\mathrm{A} 1}{ }^{\prime}$ & {$[\mathrm{J} / \mathrm{mol}]$} & $1.8135 \cdot 10^{4}$ & \\
\hline $\mathrm{k}_{02}{ }^{\prime}$ & {$\left[\mathrm{m}^{6} \mathrm{~mol}^{-2} \mathrm{~s}^{-1}\right]$} & $7.7060 \cdot 10^{3}$ & \\
\hline $\mathrm{E}_{\mathrm{A} 2}{ }^{\prime}$ & {$[\mathrm{J} / \mathrm{mol}]$} & $5.4501 \cdot 10^{4}$ & \\
\hline
\end{tabular}

Reaction rate constant values in different temperature

\begin{tabular}{|c|c|c|c|c|}
\hline & \multicolumn{2}{|c|}{ Zwitterion mechanism } & \multicolumn{2}{c|}{ Termolecular mechanism } \\
\hline $\mathbf{T}$ & $\mathbf{k}_{\mathbf{2}}$ & $\mathbf{\mathbf { k } _ { \mathbf { a } }}$ & $\mathbf{\mathbf { k } _ { \mathbf { 1 } }}$ & $\mathbf{\mathbf { k } _ { \mathbf { 2 } }}$ \\
\hline$[\mathbf{K}]$ & {$\left[\mathbf{m}^{\mathbf{3}} \mathbf{~ m o l}^{\mathbf{- 1}} \mathbf{s}^{\mathbf{- 1}}\right]$} & {$\left[\mathbf{m}^{\mathbf{6}} \mathbf{~ m o l}^{-\mathbf{2}} \mathbf{s}^{\mathbf{- 1}}\right]$} & \multicolumn{2}{|c|}{$\left[\mathbf{m}^{\mathbf{6}} \mathbf{m o l}^{-\mathbf{2}} \mathbf{s}^{-\mathbf{1}}\right]$} \\
\hline 293 & 0.6695 & $1.4624 \cdot 10^{-3}$ & $5.7115 \cdot 10^{-4}$ & $1.4971 \cdot 10^{-6}$ \\
\hline 298 & 0.8027 & $1.8879 \cdot 10^{-3}$ & $6.4706 \cdot 10^{-4}$ & $2.1783 \cdot 10^{-6}$ \\
\hline 303 & 0.9568 & $2.4167 \cdot 10^{-3}$ & $7.3004 \cdot 10^{-4}$ & $3.1305 \cdot 10^{-6}$ \\
\hline 313 & 1.3365 & $3.8676 \cdot 10^{-3}$ & $9.1862 \cdot 10^{-4}$ & $6.2446 \cdot 10^{-6}$ \\
\hline
\end{tabular}




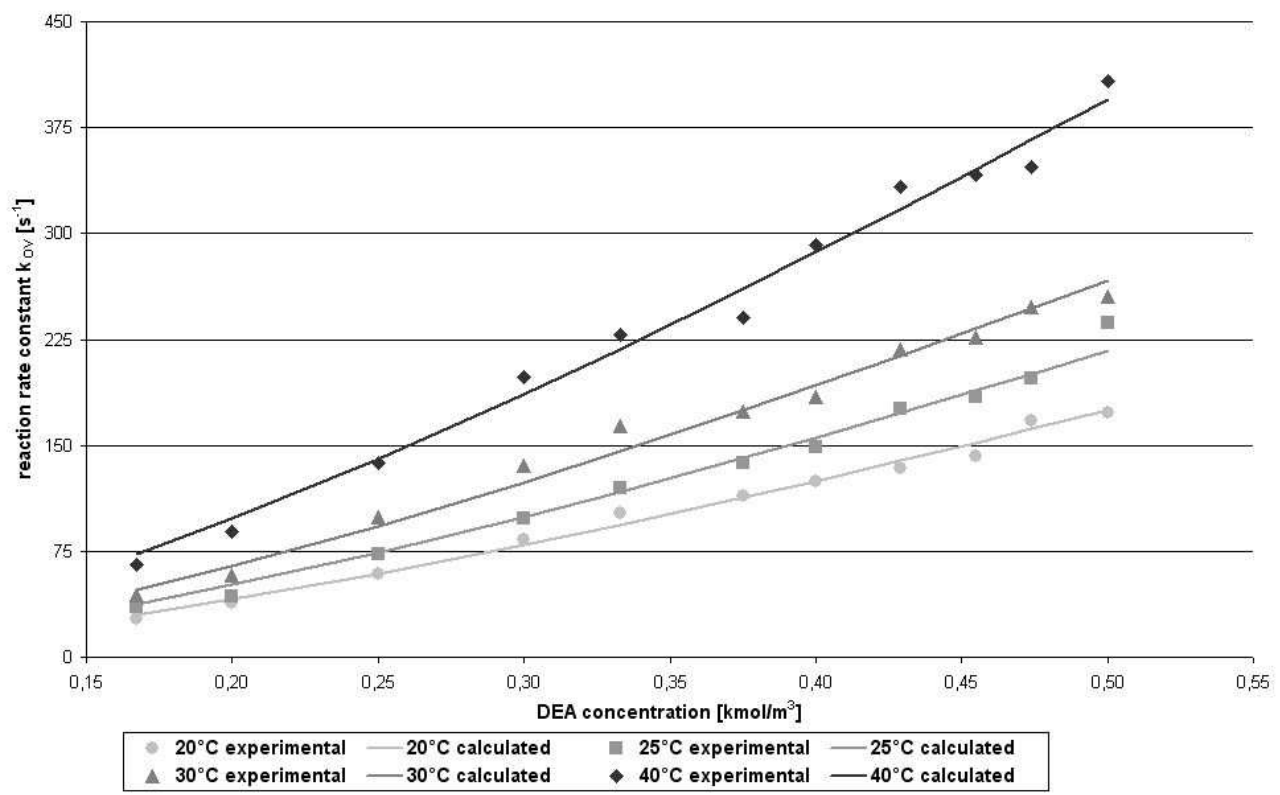

Fig. 3. Experimentally obtained pseudo-first-order reaction rate constants correlated using the zwitterion mechanism

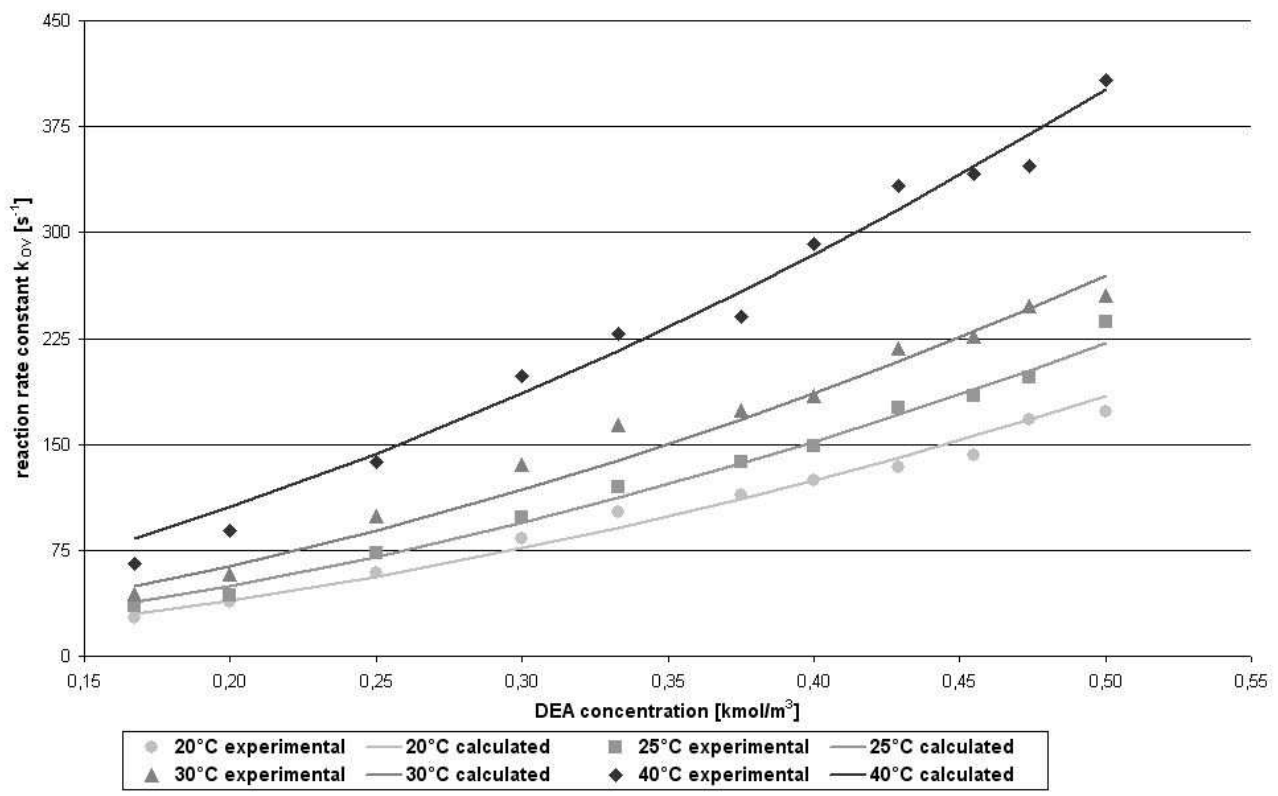

Fig. 4. Experimentally obtained pseudo-first-order reaction rate constants correlated using the termolecular mechanism 


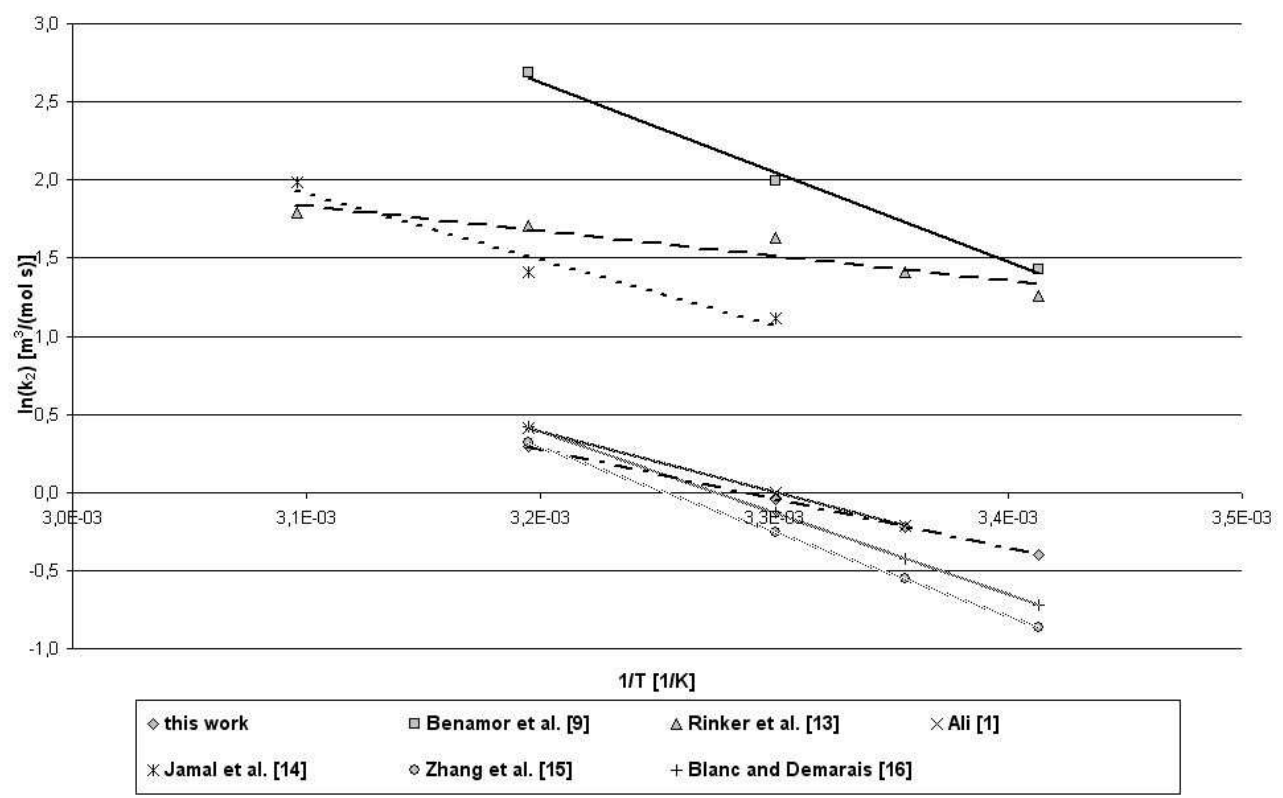

Fig. 5. Arrhenius plot of the estimates for the zwitterion formation rate constant

Figure 5 shows temperature dependence of the zwitterion formation rate constant determined by different investigators. From this plot a conclusion can be drawn that there are quite big differences in data obtained by different researchers. The data obtained in this work are comparable with the data published by Ali [1], Zhang et al [15] and by Blanc and Demarais [16].

\section{Conclusions}

The kinetics of the reaction of $\mathrm{CO}_{2}$ with DEA in aqueous solutions have been studied using the stopped-flow apparatus and the impedance spectroscopy, in which an alternating current coupled with Fast-Fourier-Transform (FFT) technique is applied for signal detection. The measurements were performed in a concentration range of (167 to 500) $\mathrm{mol} \cdot \mathrm{m}^{-3}$ and a temperature range of (293 to 313$) \mathrm{K}$. The overall reaction rate constant was found to increase with amine concentration and temperature. The $\mathrm{CO}_{2}$ reactions in DEA aqueous solutions could be explained by the zwitterion mechanism as well as by the termolecular one. The values of SSE quality index showed a good agreement between the experimental data and the corresponding fit by the use of both mechanisms. From mathematical point of view both models are equal valuable and it is impossible to estimate which one is more reasonable. The second order kinetic rate constants for the zwitterion formation determined in this work are very close to the results reported by Ali [1], Zhang et al [15] and Blanc and Demarais [16]. The experimental technique followed in this work is therefore verified and will be used for determination of kinetics of $\mathrm{CO}_{2}$ reaction in other amines. 


\section{Nomenclature}

B base (amine, water or hydroxyl ion)

DEA diethanolamine

$\mathrm{E}_{\mathrm{A}} \quad$ activation energy $[\mathrm{J} / \mathrm{mol}]$

$\mathrm{k}_{\mathrm{OV}} \quad$ observed pseudo-first-order reaction rate constant $\left[\mathrm{s}^{-1}\right]$

$\mathrm{k}_{2} \quad$ forward second-order reaction rate constant $\left[\mathrm{m}^{3} \mathrm{~mol}^{-1} \mathrm{~s}^{-1}\right]$

$\mathrm{k}_{-1} \quad$ backward first-order reaction rate constant $\left[\mathrm{s}^{-1}\right]$

$\mathrm{k}_{\mathrm{a}} \quad\left(\mathrm{k}_{2} \mathrm{k}_{\mathrm{R} 1 \mathrm{R} 2 \mathrm{NH}}\right) / \mathrm{k}_{-1}\left[\mathrm{~m}^{6} \mathrm{~mol}^{-2} \mathrm{~s}^{-1}\right]$

$\mathrm{k}_{\mathrm{B}} \quad$ zwitterion deprotonation rate constant by base (amine, water or hydroxyl ion) $\left[\mathrm{m}^{3} \mathrm{~mol}^{-1} \mathrm{~s}^{-1}\right]$

$\mathrm{k}_{1}, \mathrm{k}_{2}, \quad$ forward third-order reaction rate constant $\left[\mathrm{m}^{6} \mathrm{~mol}^{-2} \mathrm{~s}^{-1}\right]$

$\mathrm{r} \quad$ overall forward reaction rate $\left[\mathrm{mol} \mathrm{m}^{-3} \mathrm{~s}^{-1}\right.$ ]

$\mathrm{R}_{1} \mathrm{R}_{2} \mathrm{NH}$ secondary amine

$\mathrm{T}$ temperature $[\mathrm{K}]$

\section{Subscripts}

exp experimental value

cal calculated value

\section{Acknowledgement}

This work was funded by the Ministry of Science and Higher Education of Poland (Project No. N N209 102937).

\section{References}

[1] Ali SA. Kinetic study of the reaction of diethanolamine with carbon dioxide in aqueous and mixed solvent systems - application to acid gas cleaning. Sep Purif Technol. 2004;38:281-296. DOI 10.1016/j.seppur.2003.12.004.

[2] Laddha SS, Danckwerts PV. Reaction of $\mathrm{CO}_{2}$ with ethanolamines: kinetics from gas-absorption. Chem Eng Sci. 1981;36:479-482. DOI 10.1016/0009-2509(81)80135-2.

[3] Versteeg GF, van Swaaij WPM. On the kinetics between $\mathrm{CO}_{2}$ and alkanolamines both in aqueous and non-aqueous solutions - I. Primary and secondary amines. Chem Eng Sci. 1988;43:573-585. DOI 10.1016/0009-2509(88)87017-9.

[4] Caplow M. Kinetics of carbamate formation and breakdown. J Amer Chem Soc. 1968;90:6795-6803. DOI 10.1021/ja01026a041.

[5] Crooks JE, Donnellan JP. Kinetics and mechanism of the reaction between carbon dioxide and amines in aqueous solution. J Chem Soc Perkin Trans. II. 1989;4:331-333. DOI 10.1039/P29890000331.

[6] Henni A. Reply to "Comments on 'Reaction kinetics of $\mathrm{CO}_{2}$ in aqueous ethylenediamine, ethyl ethanolamine, and diethyl monoethanolamine solutions in the temperature range of 298-313 K, using the stopped-flow technique”. Ind Eng Chem Res. 2008;47:991-992. DOI 10.1021/ie0715613.

[7] SFM-20 User's Manual v. 2.1 - August 2008.

[8] MCS-200 User's Manual v. 1.1 - June 2007.

[9] Benamor A, Ali BS, Aroua MK. Kinetic of $\mathrm{CO}_{2}$ absorption and carbamate formation in aqueous solutions of diethanolamine. Korean J Chem Eng. 2008;25:451-460. DOI 10.1007/s11814-008-0077-3.

[10] Blauwhoff PMM, Versteeg GF, van Swaaij WPM. A Study on the reaction between $\mathrm{CO}_{2}$ and alkanolamines in aqueous solutions. Chem Eng Sci. 1983;38:1411-1429. DOI 10.1016/0009-2509(83)80077-3.

[11] Versteeg GF, Oyevaar $\mathrm{MH}$. The reaction between $\mathrm{CO}_{2}$ and diethanolamine at $298 \mathrm{~K}$. Chem Eng Sci. 1989;44:1264-1268. DOI 10.1016/0009-2509(89)87026-5.

[12] Marquardt D. An algorithm for least-squares estimation of nonlinear parameters. SIAM J Appl Math. 1963;11:431-441. DOI 10.1137/0111030. 
[13] Rinker EB, Ashour SS, Sandall OC. Kinetics and modeling of carbon dioxide absorption into aqueous solutions of diethanolamine. Ind Eng Chem Res. 1996;35:1107-1114. DOI 10.1021/ie950336v.

[14] Jamal A, Meisen A, Lim CJ. Kinetics of carbon dioxide absorption and desorption in aqueous alkanolamine solutions using a novel hemispherical contactor - II: Experimental results and parameter estimation. Chem Eng Sci. 2006;61:6590-6603. DOI 10.1016/j.ces.2006.04.047.

[15] Zhang X, Zhang Ch, Liu Y. Kinetics of absorption of $\mathrm{CO}_{2}$ into aqueous solution of MDEA blended with DEA. Ind Eng Chem Res. 2002;41:1135-1141. DOI 10.1021/ie010605j.

[16] Blanc CC, Demarais G. The reaction of $\mathrm{CO}_{2}$ with diethanolamine. Int Chem Eng. 1984;24:43-52.

\title{
KINETYKA REAKCJI DITLENKU WEGLA W WODNYCH ROZTWORACH DIETANOLOAMINY Z ZASTOSOWANIEM TECHNIKI ZATRZYMANEGO PRZEPEYWU
}

\author{
${ }^{1}$ Wydział Inżynierii Procesowej i Ochrony Środowiska, Politechnika Łódzka
}

\begin{abstract}
Abstrakt: W pracy przedstawiono wyniki badań kinetycznych reakcji $\mathrm{CO}_{2}$ w wodnych roztworach dietanoloaminy. Badania przeprowadzono $\mathrm{z}$ zastosowaniem techniki zatrzymanego przepływu $\mathrm{w}$ temperaturze 293, 298, 303 i $313 \mathrm{~K}$, w zakresie stężeń aminy od 167 do $500 \mathrm{~mol} \cdot \mathrm{m}^{-3}$. Stwierdzono wzrost wartości stałej szybkości reakcji pseudopierwszego rzędu wraz ze wzrostem stężenia aminy oraz temperatury. Dane eksperymentalne zostały opisane za pomocą zależności kinetycznych wynikających z mechanizmu jonu dwubiegunowego oraz reakcji trójmolekularnej. Parametry kinetyczne dla obu mechanizmów wyznaczono w oparciu o minimalizację przyjętego wskaźnika jakości (SSE). Wartości tego wskaźnika wykazały dobrą zgodność pomiędzy danymi doświadczalnymi i odpowiednimi dopasowaniami z użyciem obu modeli kinetycznych.
\end{abstract}

Słowa kluczowe: kinetyka reakcji, absorpcja $\mathrm{CO}_{2}$, model kinetyczny, dietanoloamina, technika zatrzymanego przepływu 